\title{
Need of Soft Skills for Undergraduate Urban Youth for Career Development
}

\author{
Suresh Gautam \\ Lecturer in Development Studies \\ Kathmandu University, School of Education \\ Hattiban, Lalitpur, Nepal \\ Email for correspondence: sgautam@kusoed.edu.np
}

\begin{abstract}
The paper aims to show the importance of soft skills of the undergraduate urban youth who are preparing their career within Nepal or abroad. Youth in city pursue formal education from colleges and university in Nepal. After the completion of undergraduates, they prepare themselves for the job market. In this line, I argue that those youth who have not developed their soft skills struggle much to find out a job. It also increases the urban poverty and unemployment. I employed ethnographic research approach to explore everyday life activities of urban youth showing their preparedness of career. In doing so, I am telling credible, rigorous, and authentic stories of those undergraduate urban youth who are preparing their career in Kathmandu. The research is carried out in Kathmandu with four young research participants who are going to appear their final semester examination of undergraduate level in Management stream from a private college of Kathmandu. Two of them have just started working in companies and two of them are searching jobs. Applying the soft skill perspective the paper explores the situation of undergraduate youth in Kathmandu who theoretically learned about some soft skills in colleges and university during their academic hours but they hardly practiced in working environment. The research explores that it is not enough to deliver theories of soft skills in the classroom rather practice for youth who are going to start their career in the city.
\end{abstract}

Keywords: Urban youth, soft skill and career development.

\section{Orientation: Urban Youth and Their Interest} In my one and half decade long teaching in urban school and colleges, I experienced various the challenges to lecturing modern urban youth about various subjects such as 'sociology' 'communication' and 'research method'. All most all colleagues complained about the nature of students who did not seem to be interested in any subjects. The majority of the students engaged in talking to each other, using the cell phone, sleeping on the desk, feeling lousy, listening silently in the classroom. It was not only whose lecturer was boring. I attempted to make every lecturer interesting, but I could not be able to grasp the attention on of urban youth. I learned from 
my experience that youths are not much interested in the course work so that they hardly learnt to compete in the job market. Therefore, the unemployment rate of youth has been increasing. Despite educational qualification urban unemployment has been increasing with poverty and deprivation too.

I have experienced the major problems of such situation that most of the BBA graduates like to pass the university examination. They mostly expect to complete their education and became eligible for the Middle Level Manager but they hardly get the job of assistant in Bank and financial organization. Such circumstances shows that undergraduates in Kathmandu hardly prepared a question to the work readiness during their course in colleges and university Conley (2008) states that it is important to develop a core set of skills and knowledge that will prepare them for postsecondary education and/or for work. However, youth in Kathmandu hardly seemed to be ready for the job market in the urban center. Possibly, academic institutions may prioritize more cognitive domain of students rather than be developing skills (soft and hard). Likewise, they might not be oriented to be prepared for the job market.

Urban youth showed their less interest to the formal teaching learning activities in the classroom nor did they seem to be reluctant to develop their soft skills for preparing their career in future. Urban youth mostly experience unemployment is a problem generally in Nepal because of lack of soft skills. Throughout the world, youth are often forced to take on temporary, part-time, casual and insecure jobs with poor and hazardous working conditions (Loughlin, \& Barling, 2001). Young people who enter the labour market with underdeveloped skills they could not be prepared themselves in their future career as Mitchell, Skinner, \& White, (2010) argues that hard skills are not only enough to get job for the youth in contemporary job market. In this line Schulz (2008) argues that soft skills are important to learn in college to the students which complemented to the hard skills for better job opportunities.

During my teaching career, I experienced that majority of the urban undergraduate youth seemed to be more interested in going abroad to continue their higher education. They hardly seemed to be interested in developing certain soft skills such as communication, problem solving, critical and creative thinking and negotiation skills during their undergraduate study in Kathmandu. Some of them prepared to compete for the job within Nepal but they hardly valued the usefulness of soft skills. Soft skills are set of skills, competencies, behaviors, attitudes, and personal qualities uplift an individual to work effectively uplifting their performance for attaining the organizational goals (Parker, 2008). These skills are broadly applicable and complement other skills such as technical, vocational, and academic skills. (Lippman, Ryberg, Carney, Moore \& Trends, 2015, p. 4). Exploring their preparedness of college graduate and their soft skills I employed ethnographic study.

\section{Ethnographic Research Approach}

This paper is developed from the field work of my $\mathrm{Ph}$. D research "Urban youth and their everyday life in Kathmandu". The paper has been developed incorporating the data of four participants in an undergraduate college affiliated Pokhara University where I have been teaching for a couple of years. I have selected four participants who were undergraduates. They were going to appear their final examination of Bachelors in Business Administration (BBA). I employed ethnographic research approach representing and describe youth preparedness for their professional life in a natural setting by interpreting and analyzing a shared pattern of belief and behaviour (Creswell, 2009). The ethnographic approach helps me mixing the art and science of cultural representation thereby exploring views of different participants regarding the issue of their readiness in a job market after their graduation. Thus, the main source of this paper was the information of the field from the data. 
I selected four participants: Shyam, Leela, Hari and Jeevan who are final semester students of the private college and two of them ( Leela and Hari) were working in private companies. It has been a month of their work. I taught them in a college in different semesters and I experienced much time to explore their preparation for career during their academic journey. I also observed their soft skills in the college which helped me to reflect better on the need of soft skills for preparing. Along with observation, I collected information from the field notes and informal discussion with them. After collecting field notes, writing memos and reflection I was able to generate meaning about the need of soft skills for undergraduate students. I was much aware of the quality standards of ethnography trustworthiness and credibility while I was portraying their belief and perception about the readiness of career.

\section{Soft Skills for College Graduates}

It was any day in October 2015. As soon as I reached in the college, I met Mr. Hari who was sitting under the shed of motorbike parking. I felt that he seemed gloomy. He might have gone with under pressure. I thought he was worried about his forthcoming examination. After formal greeting with him, I asked him, what happened, Mr. Hari? Why are you looking sad? Is there anything important tasks you missed in your life" I asked him. He shared, "I was going to complete my BBA soon and not much serious to the job. I was thinking about ways of getting a job in Kathmandu". After listening to Hari I reflected the current job market in Kathmandu. The job market of Kathmandu was shrunken with some commercial bank and private companies for BBA graduates. It would be difficult to get a job in a small market on the one hand and they have not prepared themselves for a career prospect on the other. They were going to complete the course work with certain hardcore cognitive knowledge but they lacked soft skills to adjust themselves in the workforce. I come up with several questions such as: Do colleges prepare themselves as a job seeker? How often undergraduate colleges provide information about job market to their students? How far they provide general guidance for job seekers in colleges?

Hari came to Kathmandu to pursue higher education and enrolled in a private college from Tanahu (One of the districts of Western Development Region) seemed to be much worried about his life and career. He was going to complete his BBA this year but he did not have any plan ahead to get the job. He could not continue further study because it was competitive and expensive to get admission in MBA in Nepal "I will search a job in the bank and other private companies. It will take a long time to get jobs in public offices in Nepal because I have to prepare a lot. it is difficult to get job in the market because I do not have any personal relation to the people who could offer me job. I don't have any specific technical skills to prepare for the job,"

It is not only Hari but Shyam, Jeevan and Leela all undergraduates got confused to find out the relevant jobs. Exploring the cause of such situation, they shared that they hardly got opportunities to develop their soft skills in their colleges which prepared them for the career. In this line Shyam shared: Actually we do have some soft skills related tasks during the course such as classroom presentation session. We take such sessions as an assignment in the most of the subjects, but teachers and students do not seem to be ready for organizing presentations. I ignored the presentation and other communicative skills. I was much focused on the grades rather than developing soft skills. Now I realized that these grades do not secure job.

Shyam and his friends believed that college environment hardly engaged their students for developing soft skills. Faculties oriented their students for academic achievement in the college rather than preparing for business industry. It was not possible to develop soft skills in the college practically though some course work covered theories of developing soft skills in undergraduate level, which was supposed to be only the part of the business industry in Nepal. 
Thus, the academic institution almost ignored developing soft skills in the formal educational setting in Nepal. Though, it is believed that soft skills are the part of the both business and educational settings (Evenson, 1999). The college has less prepared to orient students for developing soft skills of the students. In this line, Leela shared:

I did business communication in my third semester, theoretically, I know writing several kinds of letters of the business environment. I could write letters as prescribed by the text book. I only practiced such kinds of letters which were frequently asked in past examination. I hardly anticipate working culture to write letters and do develop communication skills.

I facilitated business communication in 2011as a teacher to Leela and her friends in their third semester. I realized that I failed to address the need of contemporary business organization. I was more oriented how could my students get better grades in examination rather how could my students develop skills to fit themselves in the job market. I was not only blaming students but I critically reflected the ways of teaching for preparing youth in the job market. It was not only the situation of Leela but Jeevan and Shyam had similar kind of experience. Jeevan shared that once he was in the bank to deposit college fee. It was his first time to deposit money in the bank. First of all he did not know any procedure to deposit money in the bank. He asked security guard about the process. Security Guard suggested him to fill up vouchers. He filled up the vouchers and went to the bank counter. The cashier in the counter refused to take the voucher because it was check deposit voucher. He was ashamed and again filled up the cash deposit voucher and waited in a queue.

The anecdote of Jeevan made me think about the education 'we' are imparting to undergraduate students. How does bookish or theoretical education prepare themselves as the career oriented? It is all about to blame the students but the question lies on academic institutions and teaching learning pedagogy as what kind of human resource that 'we' have been preparing. It is all because the college had hardly focused on the soft skills which are essentials for the job market. Has ever college realized the need of soft skills those enhances students ability to work and career prospects? I am also convinced that person's interactions, job performance, and career prospects (Parsons, 2008) are expected to develop during their undergraduate level. The college where I was working as a teacher less prioritized soft skills during the time of four years assimilating in their everyday life teaching learning activities to prepare themselves for their profession. Students in undergraduate level learned some both hard skills and soft skills to get a job which were not enough to compete.

\section{Readiness for the Job}

Hari joined a call center in the Month of March 2016. It was a bit easier to get a job in call centers for Hari in Kathmandu because he mostly worked in odd hours from 6 PM to 4 AM. During the first week, he enjoyed the job. He went to the office on time. He met new friends. He had dinner around 10: $00 \mathrm{pm}$ with friends. After a work, he had coffee and cigarette with friends. He found that his manager was motivating him to make sales in the office. But gradually, he found his job more challenging because he was responsible for handling the large scale of information via telephone. Moreover, if he was able to promote sales he could get incentive which was more than his basic salary. He had gone under pressure to work and communicate. He worked in odd hours and very difficult to continue his college. The first time he became familiar with the professional working culture in a call center at Kathmandu. He was reflecting the ideas those he learned in college course books such as team work, communication skills, problem solving were practically useful for his work culture. It was a wonderful experience to maintain dress code and behave with his colleagues appropriately in a professional setting. Hari was actually practicing whatever he learned theoretically in the course book that indicated that his work experiences helped him 
take responsibility, develop time-management skills, and overcome shyness with adults.

Reflecting back to my college life I question to the theories that I have learnt about different subjects I studied. I judged my communication skills, negotiation capacity, my dress code and my business etiquettes that I have never learned in my college.

Hari and his colleagues in the call center have appeared their Bachelors examination and few of them completed Bachelor's level. Hari said that he knew about various skills such as problem solving, decision making, and communicative skills more in 15 days than studying in 4 years Bachelor's in about the job preparedness. I am thinking as a faculty how do we encourage students to play an active and persistent roles to prepare themselves in a workplace? How often do I provide feedback to my students? Have I ever promoted a strengths-based learning process while I was teaching them? This indicates to develop soft skills to prepare youth in job market. No doubt, the academic institution focused more on academic rigour but hardly pay attentions in the soft skills. Leela shared her feelings:

I was totally unknown about the working culture before I joined in an online shopping company. I was confident to get grades in college but I was hesitated to communicate with seniors staff of the organization. Though the organization was not big I leared various skills to take decision on time. During the online job, I needed to take decision promptly if the customers are asking any support and discount. Usually, I went to the managers and asked the solution but the manager remained quite busy. Possibly, he did not like my frequent presence in his chamber. Then, he suggested to solve the problem myself. While I was confused in the college I usually asked my teachers instead of trying to solve them.

Leela started working for an online company in March 2016. She was computer literate. She knew a bit about the internet and email. She had all hard skills that are needed to work in the online jobs but she was not confident to achieve the target in the first month. She herself found that she did not have few critical and analytical skills so that I could not solve the problem. All participants are aware of developing technological influences and global work culture and diversity but they were restricted to the textbooks but they really gained experienced during the very short span of time in their work culture. They experienced that soft skills are also equally important as hard skills in preparing themselves in the job market from a short span of time.

These college graduates were struggling to be ready to adjust in the job market in Kathmandu that has been expanded from the physical working atmosphere to virtual work. Two of the participants work online and gained experience of the global workforce. They believed that it was not sufficient just to know about the technological advancement but it was equally important to know of dealing with the global work culture (Kalleberg, 2009). In doing so, they experienced the need of perseverance, responsibility, and self-discipline. They believe that such skills are useful for them in their future career perspective for a successful tenure.

\section{Job Market for Youth}

Youth employment is supposed to be one of the challenges for graduate youth in Kathmandu. Though there are not specific job orientation to these graduates in college and university. Mostly, these youth search jobs in private sectors such as banks, financial company and multinational companies because the private sector dominance in job market has been expanding. However, the current education system neither pay attention to produce human resource that fits in private sector. The expectation of youth in job market has been more competitive. All research participants shared that they hardly learnt about the soft skills during their course work of four years undergraduate study. Though, the curriculum of BBA envisions to prepare middle level managers but it is difficult to get job of assistants in Kathmandu. 
In this line Shyam opined

It is very difficult to get job in Kathmandu. I am planning to you to my village where I could find a job but I am not sure whether I would get job in the banks and financial institution. My educational background is management and I am not able to develop career as a teacher. I am preparing myself as a middle level manager but I hardly get opportunities in Kathmandu.

Shyam seemed to be worried about the job after his graduation. His academic performances were very good but he scared to get job. Exploring further he shared that it was not because of degrees they have but because of soft skills. All graduates applied for the post but those will be selected who demonstrated their critical and analytical skills. Similarly, communication skills are also useful to get job. Most of us in our college do not know how to communicate in formal and official way. Urban youth spent time in the college joking, kidding, playing and talking without any consideration of importance of communication.

It is not only the opinion of Shyam but rest of the participants also hesitated to practice any creative, analytical and communication skills in their course work of BBA and lagged behind the job market. Students often said that they were taught to develop such skills to get jobs by the college administration and teachers but they hardly got chance to practice such skills. Theoretically they were familiar to develop set of skills and competencies but they were not able to differentiate particular soft skills which would help them, to establish themselves in job market.

All my participants observed and targeted Bank and finance companies as a prospectus job market but they hardly analyzed particular skills needed for navigating their environment, working with others and performing well. They mostly focused on the academic skills in their college which hardly prepared themselves to adjust in the job market. Urban youth neither showed their interest to the formal teaching learning activities in classroom nor did they seem to be reluctant to develop their soft skills for preparing their career. Urban youth mostly experience unemployment is a problem generally in Nepal because of lack of soft skills. Throughout the world, youth are often forced to take on temporary, parttime, casual and insecure jobs with poor and hazardous working conditions.

The challenges and opportunities that young people are facing in the urban centers of Nepal, The mobility of youths is higher and creating many hazards in the urban centers such as unemployment, poverty and hunger at same time young students see more opportunities in the urban hubs to develop their education, career and future. Clear mismatch can be observed between demand and supply of skilled workforce especially in domestic and foreign employment sectors in the global work environment. Academic performance of the students do not capture the soft skills that are valued for the job market (Heckman, \& Kautz,2012). It was difficult to observe their preparedness for their career in the college. Most of the time they were guided for examination. We teacher motivated them to achieve academic excellences rather than developing soft skills. Despite of some formal presentation, internship and a research, the college hardly focused to develop their creative and critical thinking, problem solving skills, negotiation skills. I also personally experienced that colleges are more oriented to increase their academic proficiency rather than preparing them for future market. It created unemployment and reduced the urban poverty.

Job market for the youth has been changing with the changing speed of urbanization in Kathmandu. Likewise, it became more competitive to get job for undergraduates. Similarly, increasing unemployment situation has also created urban poverty (World Bank, 2013) . Gradual change on the urbanization has made it difficult to reduce urban poverty because urban space has been translating into the economic product and political relation more than the concrete 
development. In this line, the college hardly prepares their students for grabbing the opportunities of the job market contributing for producing human resource. Urban plans and policies more oriented to enhance the economic mobility of the city. How is it possible without proper human resources who hardly prepared for the job market in urban centers?

In the similar line it is expected from the academic institutions to produce human resources who could understand urban centers that are much affected by the industrial and commercial mobility, otherwise, it may increase urban poverty.

Acharya (2010) includes that education is the part of the human infrastructure development. However, he focuses more on the mainstream of the education (formal and non-formal) that may reduce the urban poverty in the one hand. On the other hand there is no any specific provision to reduce the urban poverty for the sustainable cities. In this line, I argue developing human resources with soft skills may reduce the problem of unemployment and reduce the urban poverty to some extent. The urban poverty in Kathmandu has been increasing but Dahal (2006) believes that urban poor but are assets of urban economy and are mostly involved in informal sector of urban economy as they have diversified and unstructured sources of income due to their irregular and seasonality of employment/works" (p. 42).

\section{Globalizing Youth and Job Market}

Undergraduates are facing various challenges developing their career in Kathmandu which increase uncertainty about economic and social developments in globalizing the world (Mills \& Blossfeld, 2005). Globalization has created a lot of uncertainty to find out the jobs for the youth in the urban center but if they develop certain soft skills to fit in the global job market. Globalization is not a single process, happening everywhere differently. Globalization is made up of a series of processes, some of which are working in opposite directions and with opposite ends (Waters, 2001, p.5). In such situation, urban undergraduates youth face more challenges to get the job in the market. Jeevan and Shyam believed that certificate of undergraduate may not be sufficient to understand the interaction and integration among the people, companies, and governments of different nations, a process driven by international trade and investment and aided by information technology (Boudreaux, 2008, p. 1). Undergraduates in Kathmandu hardly perceive the role of such changing dynamics of global working culture while they were studying in colleges. Moreover, they lived in likelihood global culture. In this line, Jeevan opined

I use the internet, email, fax machine, satellite and cable T.V, iphone. I am connected to the global culture but I spent most of the time in social media chatting with friends. I hardly use these skills to find out the proper jobs in the global market. I am learning to be global in my everyday life but I am not prepared to fit myself in the global working force.

Jeevan was gradually adapting global ways of living but he hardly connected to the global ways of earning. His thought of being global was to examine the day to day life of urban people, putting cultural aspects in mind. How people's day to day life has been impacted by the waves of globalization. The changes in day to day life like eating, listening music and playing games, reading books etc have been explained with the perspective of globalization.

Though, globalization is not merely an economic phenomenon; rather it covers all the aspects of modern life: the economic, the cultural, the political, the humanitarian, the social, and the ecological (Dasgupta, 2004, p. 15), It also influences the socialization of the youths and thus helped to frame their future career and job. Globalization brings together the people from different races, cultures, ethnic groups and socioeconomic classes into closer contact with each other. How far urban undergraduates learn the soft skills of respecting urban diversity? How far they practice to address the economic and cultural divide. As Dasgupta (2004) states, the fear and the injuries that globalization can inflict in each and every facet of our economic, 
cultural, political, and social lives but most of the time youth became more vulnerable to get the job.

In relation to my epistemic understanding that cities are always questioned in the age of globalisation for justice and have asked how people relate to cities in the face of current processes of disjunction and interconnectedness (Donner \& De Neve, 2006, p.4). Globalization creates job opportunities in the job market but it often seeks employability skills to get job with soft skills such as personality, attitude and behaviour that help in non-technical and non-domain skills. These are collection of several skills such as team building, leadership, motivation, time management, presentation skills (Rao, 2010, p. 3). However, the undergraduates like Jeevan and Leela in the colleges hardly practice to work in the global work force. They did not conducive environment in the college to develop their soft skills such as addressing the need of globalization. "Most job candidates declare to have highly-developed soft skills, however, these capabilities cannot be confirmed by any of formal certification, as this situation happens with most other competence." (Slawinska, \& Villani, 2014, p. 56).

\section{Reorientation: Need of Soft Skills}

Carrying out an ethnography in a private college where BBA programme has been running, I explore the preparedness of undergraduates' preparedness for the career. It is observed that most of the undergraduates are struggling to get jobs in the job market but it difficult to prove themselves competent because they lack soft skills such as responsibility, integrity, communication, courtesy, social skills, flexibility, professionalism, teamwork and positive attitude (Robles, 2012). They realized that soft skills are important to enter into the labour market despite of their academic qualification. During the four years of their academic performance in the BBA programme they theoretically learnt about some soft skills such as communication skills, negation skills, and problem solving but they hardly practice such skills in the real working environment. Academic institutions mostly focused on the academic excellent rather than developing soft skills therefore students struggle more to find appropriate job placement in the job market.

Likewise, job market in Kathmandu has been changing rapidly in Kathmandu for a decade when the access of communication has been developed in Nepal. However, the youth used changed communication for the entertainment rather than connecting themselves for the labour market. In doing so, they hardly adopted soft skills to suit in the globalized job market. They are not prepared to address the changing working culture in the globalization. It is realized that it is enough to prepare undergraduates students academically sound in the colleges and university but it is important to prepare for the job market. In so doing, academic institution are expected to prioritize soft skills in a practical way, otherwise, it increases urban unemployment and poverty. Thus, it is the need of the academic institution to prepare their students for the job market by offering relevant soft skills during their formal undergraduate course in management.

\section{Reference}

Acharya, S. (15 Sep, 2010). Urban Poverty. Retrived from myrepublica.com on 9/92013.

Conley, D. T. (2010). College and Career Ready: Helping all Students Succeed Beyond High School. San Francisco: Jossey-Bass.

Creswell, J. W. (2009). Research design : qualitative, quantitative, and mixed methods approaches (3 rd ed). Los Angeles : Sage Publication.

Dahal, K. (2006). Urban poverty: A study of income patterns and processes of the poor families in Kathmandu. Banking Journal,1,1. 29-45.

Dasgupta, S. (Ed.). (2004). The changing face of globalization. New Delhi: Sage Publications.

Donner, H. \& De Neve, G. (2006).The meaning of the local: politics of place in urban India. New York: UCL Press. 
Heckman, J. J., \& Kautz, T. (2012). Hard evidence on soft skills. Labour economics, 19(4), 451464.

Kalleberg, A. L. (2009). Precarious work, insecure workers: Employment relations in transition. American sociological review, 74(1), 1-22.

Lippman, L. H., Ryberg, R., Carney, R., \& Moore, K. A. (2015). Child Trends. What do children need to flourish. New York: World Bank

Loughlin, C., \& Barling, J. (2001). Young workers' work values, attitudes, and behaviours. Journal of occupational and organizational Psychology, 74(4), 543-558.

Mills, M., \& Blossfeld, H. P. (2005). Globalization, uncertainty and the early life course. In H. P. Blossfled, M. Miles \& K. Kurz (Eds.) Globalization, uncertainty and youth in society: The losers in a globalizing world pp. 1-23. New York: Routeledge

Mitchell, G. W., Skinner, L. B., \& White, B. J. (2010). Essential soft skills for success in the twenty first century workforce as perceived by business educators. The Journal of Research in Business Education, 52(1), 43.

Rao, M. S. (2010). Soft skills: enhancing employability: connecting campus with corporate. IK International Pvt Ltd.

Robles, M. M. (2012). Executive perceptions of the top 10 soft skills needed in today's workplace. Business Communication Quarterly, 75(4), 453465.

Schulz, B. (2008). The importance of soft skills: Education beyond academic knowledge. NAWA Journal of Language and Communication. 146154

Slawinska, K., \& Villani, C. S. (2014). Gaining and strengthening 'soft skills' for employment. Edukacja ustawiczna doroslych, (3 (86)), 44-53.

Waters, M. (2001). Globalization (2nd ed.). New York, NY: Routledge. 